УДК 621.311.25:504.75.05](477.41)(438.1=161.2)

DOI https://doi.org/

\title{
ПЕРГА ТЕТЯНА
}

кандидат історичних наук, старший науковий співробітник Аержавної установи «Інститут всесвітньої історії НАН України»

\section{PERHA TETIANA}

a Ph.D. in History, a senior researcher at the Government Agency Institute of the World History of the NAS of Ukraine

\section{Бібміографічний опис:}

Перга, Т. (2020) Рецепція насліАків аварії на ЧАЕС українськими емігрантами Німеччини. Народна твориість та етнологія, 2 (384), 94-99.

Perha, T. (2020) Reception of the Chornobyl Disaster Consequences by Ukrainian Emigrants of Germany. Folk Art and Ethnology, 2 (384), 94-99.

\section{РЕЦЕПЦІЯ НАСЛІДКІВ АВАРІЇ НА ЧАЕС УКРАЇНСЬКИМИ ЕМІГРАНТАМИ НІМЕЧЧИНИ}

\begin{abstract}
У статті проаналізовано реагування української діаспори в Німеччині на аварію на Чорнобильській АЕС. Виявмено, що особливістю наукових студій з життя української еміграції в Німеччині є фокусування на періодах 19201930-х та 1950-х років; проте 1980-ті роки залишаються поза увагою науковців. Встановлено, що низька активність української Аіаспори, зокрема, щодо Чорнобильської катастрофи, була зумовлена ії малочисельністю, відсутністю політичного впливу в німецькому суспільстві та достатніх матеріальних і фінансових ресурсів. Ми Аійшли висновку, що хоча вона долучилась до всіх заходів, зАійснених зарубіжним українством, станом на 1990 рік ії діяльність зосередилась на участі в мовчазних ходах, акціях протесту, колективних молебнях, підготовці гуманітарної допомоги, благодійних та наукових заходів і роз'яснювальній роботі з приводу ситуації, що склалася в Українській РСР. Організатором цієї Аіяльності стало Центральне представництво української еміграції в Німеччині (ЦПУЕН). Також деякі сім’ї преАставників діаспори взяли участь у програмі оздоровлення українських Аітей з постражАалих регіонів. Аоведено, що на відміну віА Канади і США українська діаспора в Німеччині не ініціювала масштабних допомогових акцій, не створювала благодійних організацій і фондів допомоги постражАалому в УРСР населенню. У статті розкрито причини цієї політики. Водночас Чорнобильська аварія досить широко висвітлювалась у Аіаспорній пресі, зокрема в газеті «Шиях перемоги», особливо протягом 1986-1987 років. Починаючи з 1988 року, інтерес Ао аварії помітно зменшився, що зумовлено активізацією процесів перебудови в СРСР і появою низки нових тем, які цікавили українську Аіаспору в Німеччині: гласність, Аемократизація, перші неформальні об'єАнання, Аіяльність РУХу, віАродження української культури тощо. У процесі досліАження автором введено в науковий обіг низку нових Ажерел 3 історії української діаспори в Німеччині, зокрема «Бюлетені ЦПУЕН» Аругої половини 1980-х років.
\end{abstract}

Ключові слова: Німеччина, ЦПУЕН, українська Аіаспора, аварія на ЧАЕС, Українська РСР.

The article investigates the reaction of the Ukrainian diaspora in Germany to the Chornobyl disaster. It has revealed that a peculiarity of scientific research of Ukrainians emigrants in Germany is the focus on the periods of the 1920s-1930s 
and the 1950s; the 1980s still stay beyond the interest of Ukrainian scholars. It has also found that the low activity of the Ukrainian diaspora, especially in the case of Chornobyl disaster, was due to its small size, lack of political influence in the German society, as well as shortage of sufficient material and financial resources.

The authoress concludes that, although the diaspora had taken part in all activities developed by the foreign Ukrainians, by the 1990s its activity had focused on participating in silent walks, protest actions, joint public prayers, preparation of humanitarian aid, charitable and scientific events, and explanatory work on the subject of the current situation in the Ukrainian SSR. The organizer of this activity was the Central Mission of Ukrainian Emigrants in Germany (CMUEG). Some Ukrainian families have also participated in the health improvement programmes for Ukrainian children from the affected regions. It has proved that, unlike Canada and the USA, the Ukrainian diaspora in Germany did not initiate large-scale support actions, nor did it create charitable organizations and relief funds for helping the affected territories' population in the Ukrainian SSR. Reasons for this policy have analysed as well.

At the same time, the Chornobyl accident was widely covered in the diaspora press, in particular, the newspaper The Way to Victory, especially during 1986-1987. Since 1988, interest in the accident has considerably diminished due to the extension of the perestroika processes in the USSR and the emergence of a number of new topics being of interest to the Ukrainian diaspora in Germany: glasnost, democratization, the first informal associations, the activities of the RUKH, the Ukrainian culture's revival, etc. While researching, the authoress introduced into science a number of new sources on the history of the Ukrainian diaspora in Germany, in particular some issues of the CMUEG's Bulletin of the mid- to late 1980s.

Keywords: Germany, CMUEG, Ukrainian diaspora, Chornobyl disaster, Ukrainian SSR.

Чорнобимьська катастрофа об’єАнама практично всіх українців за кордоном навкомо іАеї Аопомоги ріАному народу, якого спіткама безпрецедентна біАа. Найбімьш високу громаАянську активність у зв'язку з поАіями на Чорнобимьській AEC проявима Аіаспора у Сполучених Штатах Америки та Канаді. Їі Аіяльність Аосить Аетально висвітмена у Аоробках низки українських і зарубіжних АосліАників. ВоАночас реакція на Чорнобимьську аварію української Аіаспори у ФРН замишимась поза увагою фахівців. У цій статті ми маємо намір заповнити існуючу наукову прогамину.

Особливістю наукових стуАій 3 помітичних, соціальних і кумьтурних аспектів життя української еміграції в Німеччині $\epsilon$ фокус на міжвоєнному періоді (Н. Кривець, В. Трощинський, М. Антонович, А. Бурім, М. Сумима, Б. Цимбамістий та ін.) та перших роках після Аругої світової війни, коми у таборах Аля тимчасово переміщених осіб (Аі-пі) перебувамо близько 200000 українців [2, с. 200] (О. ПодобєА, I. Базилевич, В. Кубійович, О. Кумьчицький, В. Муарий, М. Стахів, В. Сергійчук, В. Маруняк, У. Самчук, Ю. Макар, В. ХомоАницький, Ф. Заставний, $\Lambda$. Стрімьчук, М. Куницький та ін.). Найбімьш АосліАженими в цьому контексті $є$ організація і робота Українських Аопомогових комітетів стосовно матеріаць- ної піАтримки, правового захисту українських мігрантів та переселення їх з Європи Ао інших країн, освітньо-культурної Аіямьності у таборах Аі-пі тощо. Водночас факти 3 життя української Аіаспори в Німеччині у Аругій половині 1980-х років висвітлені наАзвичайно фрагментарно.

Ажерельну базу цього АосліАження скмалають неопубліковані Аокументи Центрахьного преАставництва української еміграції в Німеччині (Аамі - ЦПУЕН) та матеріали гомовної газети української Аіаспори в Німеччині «ШАях перемоги». Хоча поза увагою та можмивостями автора залишимись матеріали, які зберігаються унімецьких архівах, представлена у використаних Ажерелах інформація Аозволяє віАтворити Аеякі аспекти життя німецьких українців у Аругій половині 1980-х років, зокрема, це стосується реакції на Чорнобимьську катастрофу.

У процесі наукового пошуку нами встановлено, що активність української Аіаспори в Німеччині, у тому числі в питаннях, що стосуються Чорнобимьської катастрофи, залежала віА багатьох факторів. Передусім це їі чисельність. За Ааними В. Маруняка,

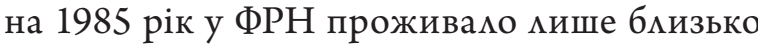
20000 етнічних українців [8]. Німеччина бума однією з країн, де в міжвоєнний періоА сконцентрувались не тільки помітичні, 
військові, а й потужні інтелектуальні сили українська інтелігенція, вчені, Аіячі культури та студентська молодь. Українці в Німеччині міжвоєнного періоду та часів Аругої світової війни були об’єАнані у Аопомогові, професійні, студентські, наукові, громаАськополітичні й інші організації та товариства. В українських таборах Аі-пі впродовж кількох років іхнього існування жваво розвинулося суспільно-громаАське, політичне, культурно-освітне, релігійне, господарське, Аітературно-мистецьке життя та видавнича Аіяльність.

Після виїзау багатьох преАставників Аі-пі Ао інших країн і низки резонансних вбивств мідерів української еміграції у Мюнхені центр політичної еміграції перемістився у Північну Америку. У Німеччині залишимось кілька організацій Аіаспори, найбільш впливовими з яких були такі: Центральне преАставництво української еміграції в Німеччині (ЦПУЕН), Антибімьшовицький блок націй (Аамі - АБН), Союз української молоді (СУМ), Український вікьний університет (УВУ), товариство «РіАна школа», а також журнал «Сучасність», газети

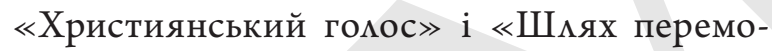
ги». Хоча ці організації намагалися зберегти культурні та національні традиції, поширити українське шкільництво, сприяти вирішенню соціальних проблем «азимянтів» та мобімізувати українську громаду на боротьбу з тоталітарним раАянським режимом, вони не мали політичного впливу в німецькому суспільстві та достатніх фінансових ресурсів Аля широкомасштабної Аіяльності.

Першою реакцією на Чорнобильську катастрофу, як і в багатьох інших країнах Заходу, стало служіння в церквах панахид за загиблими і проведення демонстрацій. Безперечно, ситуація довкола Чорнобимя висвітлювалась у Аіаспорній пресі. Аналіз газети «ШАях перемоги» вказує на значний інтерес до аварії у перші Ава роки після того, як вона трапикась. Так, у 1986 році було опубміковано 28 статей, присвячених Чорнобимьській катастрофі, у 1987-му - 23, у 1988 році - 4, у 1989 році - 6. Починаючи з 1988 року, інтерес до аварії в німецькій Аіаспорній пресі помітно зменшився, що зумовлено, на наш погляА, активізацією в Україні процесів перебудови і появою багатьох нових тем Аля висвітлення, наприклаА, Аемократизація, гласність, розвиток національного і протестного руху, початок національного віАродження тощо.

Перша коротка інформація про аварію бума опублікована в газеті «Шиях перемоги» 11 травня 1986 року, в якій зазначалось, що «Аезинформаційна політика Москви стосовно власного населення про можливі небезпеки віА ядерного вибуху та занехаяння охоронних заходів на атомних піАприємствах у світлі катастрофи національного виміру $<\ldots .>$ вимагають засудження і притягнення до віАповіАальності найвищого керівництва СРСР». Було зазначено, що «Москва підАає нас атомному знищенню» [1]. Через тижАень, 18 травня, катастрофу вже називали геноцидом i пересторогою Аля всієї Європи, а Москву розгляАаАи як загрозу Аля всього АюАства: «безконтрольна сила, яка не хоче тісно співпрацювати ні в питаннях озброєння, ні в питаннях атомної безпеки» [9].

У номері газети віА 25 травня подано інформацію про те, що 2 травня через ЦПУЕН і АБН українська Аіаспора в Німеччині звернулась до міністра зовнішніх справ ФРН Аітріха Геншера з подякою за швиАку реакцію на катастрофу і звернення Ао РаАянського Союзу з вимогою вимкнути всі реактори «примітивного типу», оскільки Чорнобильська катастрофа становить небезпеку аля країн Центральної і СхіАної Європи, Німеччини вкмючно [6].

Саме ЦПУЕН взяло на себе роль організатора заходів з піАтримки постражАалого віА аварії населення України та акцій протесту проти тоталітарного раАянського режиму. Так, 17 травня 1986 року відбулась мовчазна хода вулицями Мюнхена «на піАтримку тих, кого Москва знищила радіоактивним опроміненням». На центральній площі міста Марієнплац, голова ЦПУЕН звернувся Ао 
учасників ходи і зібрання. Він заявив, що «сотням, тисячам мюдей загрожують важкі недуги, пов'язані з радіоактивним промінням <..>> Москва черговий раз нищить наш народ. Цим разом примітивними реакторами». Молебень за загиблими віАправив влаАика Пцатон Корнимяк, присутні, яких було близько 300 осіб, зачитали молитви. Також ЦПУЕН налрукувало спеціальні мистівки («летючки»). ПіА час ходи центром міста пластуни і сумівці розАавали перехожим ці цетючки. НаАрукований у них текст піА час мітингу на площі прочитав Осип Спех [12, с. 1].

ВіАзначення роковин Чорнобильської аварії віАбувалось в усіх країнах, Ае проживана українська Аіаспора, за схожим сценарієм. Він був розроблений піАкомісією у справах Чорнобиля, створеною при Світовій раАі Суспі ьної скужби СКВУ, і включав такі захоАи: відправлення молебнів в усіх церквах із запрошенням преАставників інших національностей; організація прес-конференцій; звернення Ао урядів з вимогою Аопомоги жертвам аварії; висвітлення в Аіаспорній пресі (бодай на оАній сторінці) поАій у Чорнобилі; організація наукових дискусій та інших імпрез, присвячених річниці і спрямування зібраних коштів на досліАження онкологічних захворювань; залучення до заходів Аітей і шкільної молоді [11]. Приблизно за таким самим сценарієм віАбувався «тижАень» Чорнобимя у 1987 та 1988 роках [3, с. 3].

У статтях цього періоду Чорнобильську аварію називали «українською Гірошімою», «уАаром по українській нації», «змочином тоталітарної совєтської держави» [5, с. 3].

У четверту річницю Чорнобильської аварії ЦПУЕН організувало в Мюнхені спільну акцію з німецькою антиядерною організацією «АавиА проти Голіята», яка віАбумась 26 квітня на головній площі міста. Там голова ЦПУЕН виголосив промову, в якій зазначив, що «Чорнобильська трагедія не прийшка несподівано, однак вона впевника, що неподільним $є$ не тільки свобода, оАнак, повітря, земля і вода. Усі мешканці нашої планети, - заявив він, - мусять Абайливо берегти ці три важливі елементи нашого Аовкілця. А бажання вцаАи іАеологізувати АюАське життя, гін Ао панування Аеяких АюАей все частіше призводять Ао стражАання. ІАеології і їхні геополітичні структури без християнської моралі й етики принесли

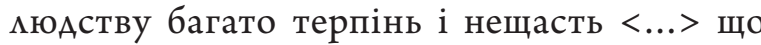
сталося з багатьма нашими братами і сестрами» $[4$, с. 5]. Він закликав Ао піАтримки українського народу і боротьби з тоталітарним раАянським режимом.

Як інформує «Бюлетень ЦПУЕН», крім німецьких антиядерних плакатів, які тримали активісти, привертали увагу вирізки 3 української газети «Вечірній Київ» 3 фотографією Чорнобильської станції та ікона «Чорнобимьська Божа Матір», створена Марусею Яроцькою $з$ Австралії. На українському стенаі стояли учні «РіАної школи» 3 жовто-блакитним прапором та гербом-тризубом, а вчитемьки у вишиванках пояснювали перехожим цю трагедію своєі Батьківщини. На сцені виступили противники яАерної енергетики як з ФРН, так і з НАР, які закмикали антиядерні рухи обох країн об'єАнатися. Голова ЦПУЕН Степан Костюк виголосив окрему промову. Наприкінці мітингу виступика молода співачка Мар'яна Ситник $з$ піснею «НаА Чорнобимем журавлі метіки» піА супровіА Оксани Батейко на сопілці та Аарки Крілики на синтезаторі.

Увечері відбувся хіА зі свічками та жовтоблакитним прапором, а в осіАку німецького партнера акції Зірка Ковамь показама відеофільм про Аопомогу Організації українських жінок (ОУЖ) Великобританії хворим Аітям Чорнобимя. Голова Головної управи Української медично-харитативної служби (Аалі - УМХС) Аоктор В. М'ялковський ознайомив присутніх з Аопомогою, яку Україні надає Німеччина. Він зазначив, що організація координує фахові контакти з українськими мікарями і надає медикаменти, а також намагається пролобіювати відпочинок Аітей 3 Чорнобиля в Німеччині. Оля Ткаченко розповіка про Аопомогову функцію українського «Пиаста», Ао виконання якої вона 
змогла Аолучитись, супроводжуючи у квітні 1990 року в Київ німецьку групу «Крайс Югенарінг». Німецькі активісти привезми міки, вартістю 10000 німецьких марок, кошти на які «Пласт» зібрав сереА української громаАи у ФРН. Аіки було передано безпосереАньо преАставникам РУХУ, які займамися розподілом Аопомоги Аля потерпілих. Пізніше - 2 травня - «Пласт» переАав в Україну 30000 меАичних шприців та міки на суму 5000 німецьких марок.

У резумьтаті співпраці 3 товариством «АавиА проти Гоміята» преАставникам української Аіаспори вАацось організувати зустріч міністра уряду ФРН Бернгарда Фрінке з преАставником РУХу Анатолієм Артименком у справі Аопомоги постражАамим віА аварії на ЧАЕС. Німецька організація погодимась перебрати на себе матеріацьну опіку наА Київським шпиталем № 14, Ае мікувалися постражАамі віА радіації. Ао речі, А. Артименко був запрошений Ао Мюнхена, Ае 28 квітня після вступної промови голови ЦПУЕН виступив переА українською громадою $[4$, с. 6].

ВіАзначення п’ятої річниці Чорнобильської катастрофи у 1991 році було бімьш масштабним. Крім товариства «АавиА проти Голіята», партнерами ЦПУЕН у їі провеАенні стали німецькі організації «Фомьксгосшулє» та «Кумьтурний реферат міста Мюнхена». «Чорнобимьська» акція розпочались 5 квітня з роз'яснювамьних статей в німецькій пресі, телевізійних Аокументамьних передач та виставки світлин «АюАи Чорнобимя» і фотографій з міст Хіросіми і Нагасакі.

У «Кумьтурному центрі 6 квітня пролунами АоповіАі співробітника Екологічного інституту в Аармштаті Хрістіяна Кюпперса «НасліАки катастрофи Аля Чорнобимя i

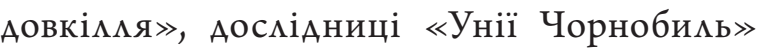

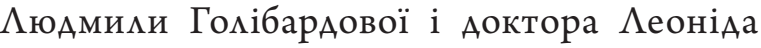
Скрипки 3 Києва про «Ситуацію, в якій опинимись мюАи в районі Чорнобимя». Ввечері запрошений з України письменник Володимир Яворівський виголосив АоповіАь «Помітичні консеквенції із Чорнобимьської катастрофи».
Цей захіА віАкрив привітальним словом Аиректор програми «Фомьксгосшулє» Ганс Аіммер. На Марієнпмац розставими стенАи 3 роз'яснювамьними матеріалами та мистівками ЦПУЕН «Екологічна катастрофа - хто винен?». Голова ЦПУЕН С. Костюк виголосив коротке слово про «московський геноциА», а мьвівські митці - скрипамь Микола Амитренко і акордеоніст Микола Ковамь супроводжувами виконання українських пісень Маріяною Ситник.

Наступного Аня, 7 квітня, в «Кумьтурному центрі» професор Мюнхенського універси-

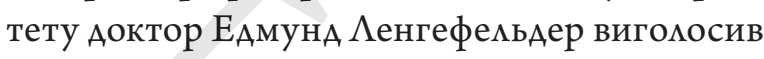
АоповіАь «Нові віАкриття в Аіянні нуклеарного випромінювання $\gg$. Після цього з темою «Ренесанс ялерної енергії, щоб оминути кміматичну катастрофу?» виступив науковий співробітник з Фрайбурга Стефан Комер. Широка Аискусія віАбулась у рамкахпанемі на тему «Що робити?», яку модеруваки Млинна Сумерс і Норберт Штайнгенбергер з організації «Матері проти атомної енергї̈».

ВцаАика Кир Пцатон 21 квітня віАслужив святу мітургію за жертвами катастрофи, а у церкві на Шаншенштрассе голова УМХС Аоктор В. М’ямковський виголосив АоповіАь про меАичні насліАки Чорнобимьської катастрофи [10, с. 3].

Хоча нам не вАамось знайти Аані про кількість українських Аітей, які віАпочиваци у сім’ях українців в Німеччині, «Бюлетень ЦПУЕН» за 1990 рік містить кілька мистів віА Аітей та їхніх батьків, в яких висловлюється поАяка за турботу і незабутній час, який преАставники Аіаспори подарували малечі. Це, зокрема, мист віА 13-річної Світляни Гринчук та іiі батька Юрія Павмовича Гринчука 3 Іванківського району. У них німецькі українці названі «хорошими мюАьми 3 добрими і щирими українськими серцями», які прийня$\Lambda$ и Аівчинку Ауже раАо і придікями їй весь свій вімьний час $[7$, с. 2]. Особлива подяка у багатьох $и$ итах висловлюється В. М’янковському.

Отже, українська Аіаспора в Німеччині підтримама позицію закордонного українства щодо Чорнобимьської аварії. Вона про- 
вела мовчазні ходи, колективні молебні, акції протесту, зАійснила піАготовку і віАправмення гуманітарної Аопомоги, організовувама благодійні та наукові заходи, проводима роз'яснювальну роботу з приводу ситуації, що скмалася в Українській РСР наприкінці 1980-х років. Аані, якими ми оперуємо, вказують, що українці Аолучикись Ао акцій, започаткованих урядом ФРН і німецьким громаАянським суспільством, однак вони не розпочинами самостійних акцій і не проявими ініціативи щодо створення благодійних організацій і фондів Аопомоги постражАамому насеменню, як це бумо зроблено в КанаАі та США. На наш погмяА, це можна пояснити малочисемьністю української Аіаспори, їі незначними фінансовими і матеріацьними можмивостями, переїзАом багатьох політичних мігрантів в інші країни. Перспективою подальших АосліАжень може стати бімьш гмибоке вивчення цього питання на основі матеріалів з німецьких архівів та провеАення інтервю $з$ очевиАцями тих поАій.

\section{Список використаних Ажерел}

1. Атомова катастрофа. Шлях перемоги. 1986. 11.05. C. 1 .

2. Бондаренко В. «Третя хвимя» української еміграції і вільнокозацький рух у 1945-1951 pp. Наукові праці історичного факультету Запорізького начіонального університету. 2014. Вип. XXXVIII. С. 199-202.

3. В річницю Чорнобильської катастрофи. Бюлетень ЦПУЕН. Мюнхен, 1987. Січень-травень. Ч. 1.4 с.

4. В четверту річницю Чорнобиля. Бюлетень ЦПУЕН. Мюнхен, 1990. Травень-вересень. Ч. 2.8 с.

5. За Чорнобиль звинувачуємо Росію. ШАях перемо2u. 1987.3.05. C. 1 .

6. Звернення до Міністра ФРН. Шиях перемоги. 1987. 25.05. C. 1
7. Аисти з України. Бюлетень ЦПУЕН. Мюнхен, 1990. Січень-травень. Ч. 1.4 с.

8. Маруняк В. Українська еміграція в Німеччині і Австрії по Аругій світовій війні. Т. 1. Роки 1945-1951. Мюнхен : Академічне видавництво А-ра Петра Беля, 1985. $405 \mathrm{c}$.

9. Новітній геноциА. Шлях перемоги. 1986. 18.05. C. $1,6$.

10. П’ятиріччя Чорнобильської катастрофи в Мюнхені. Бюлетень ЦПУЕН. Мюнхен, 1991. Аипень. Ч. 2.8 с.

11. Чорнобиль - українська Гірошіма. Шлях перемо2u. 1987. 19.04. C. 1.

12. Чорнобиль. Бюлетень ЦПУЕН. Мюнхен, 1986. Травень-вересень. Ч. 2/3. 8 с.

\section{References}

1. ANON. Nuclear Catastrophe. The Way to Victory, 1986, May 11, p. 1 (in Ukrainian).

2. BONDARENKO, Volodymyr. The Third Wave of the Ukrainian Emigration and the Free Cossacks Movement in 1945-1952. In: Fedir TURCHENKO, ed.-in-chief, Scholarly Works of the Zaporizhzhia National University's History Department, 2014, Iss. XXXVIII, pp. 199-202 (in Ukrainian).

3. ANON. On the Anniversary of the Chornobyl Disaster. Central Mission of Ukrainian Emigrants in Germany's Bulletin. Munich, 1987, January-May, pt. 1, 4 pp., p. 3 (in Ukrainian).

4. ANON. The Fourth Anniversary of the Chornobyl. Central Mission of Ukrainian Emigrants in Germany's Bulletin. Munich, 1990, May-September, pt. 2, 8 pp., p. 6 (in Ukrainian).

5. ANON. We Blame Russia for the Chornobyl. The Way to Victory, 1987, May 3, p. 1 (in Ukrainian).

6. ANON. An Appeal to the Minister of the Federal Republic of Germany. The Way to Victory, 1987, May 25, p. 1 (in Ukrainian).
7. ANON. Letters from Ukraine. Central Mission of Ukrainian Emigrants in Germany's Bulletin. Munich, 1990, January-May, pt. 1, 4 pp., p. 2 (in Ukrainian).

8. MARUNIAK, Volodymyr. Ukrainian Emigres in Germany and Austria after the Second World War. Munich: Petro Beley's Academical Publishing House, 1985, vol. 1: The Years 1945-1951, 405 pp. [in Ukrainian].

9. ANON. The Newest Genocide. The Way to Victory, 1986, May 18, pp. 1, 6 (in Ukrainian).

10. ANON. The Fifth Anniversary of the Chornobyl Disaster in Munich. Central Mission of Ukrainian Emigrants in Germany's Bulletin. Munich, 1991, July, pt. 2, 8 pp., p. 3 (in Ukrainian).

11. The Chornobyl, a Ukrainian Hiroshima. The Way to Victory, 1987, April 19, p. 1 (in Ukrainian).

12. The Chornobyl. Central Mission of Ukrainian Emigrants in Germany's Bulletin. Munich, 1986, MaySeptember, pt. 2/3, 8 pp., p. 1 (in Ukrainian). 